DOI: https://doi.org/10.24123/jbt.v3i02.2507

\title{
CONSIDERATION OF EMPLOYEE MOTIVATION IN THE ERA OF INDUSTRY 4.0
}

\author{
Edith PrimadianaTedjokusumo
}

\author{
Secretary Study Program, Politeknik Ubaya, Surabaya \\ E-mail: edithprimadiana@gmail.com
}

\section{Abstract}

Industry 4.0 has been a hot issue for the development of worldwide trend, including in Indonesia. Indonesia stepped up to join the world's crowd in the industry development by the statement of Indonesia's President to be one of the top ten biggest global economies by 2030. In the same time, the government of Indonesia has called for how human resources should deal with industry of 4.0. The preparation of entering Industry 4.0 has become really tremendous since last year. As a result, the human resources get a lot of attention. The objective of this paper is to identify the requirements in fulfilling the implementation of the Industry 4.0 by the fundamental of human resources, that is, employee motivation. This paper proposes the reflection for employee motivation towards Industry 4.0. It is also to represent the narration of thoughts and the followed-up in industry 4.0. The limitations of this paper are only on topics of employee motivation and industry 4.0.

Keywords: Employee Motivation, Industry 4.0, Human Resources.

\section{Introduction}

Global Innovation Index made ranks for the countries in the world regarding innovation performance of select economies. Indonesia is still on the same spot as last year's rank, number 85 of 129 countries. (https://infografik.bisnis.com/read/20190814/547/1136393/revolusi-industri4.0-inovasi-dan-kualitas-sdm-indonesia). It is not just a number. The rank is still far away from what has been expected, but the reality cannot be denied. The industry, once again, changes. Mr. Joko Widodo, the Indonesian President, already shared his vision on the roadmap of "Making Indonesia 4.0". It has been officially launched by the Indonesian government last year (https:// www.cekindo.com/blog/industry-4-0-indonesia-challenges-opportunities). The President believes that the realization will drive Indonesia to become one of the top ten biggest global economies by 2030 . As the role in Industry 4.0, from the view of Indonesian economy, the manufacturing sector accounted for $20 \%$ of the GDP of Indonesia in 2017. It is nearly one in five of the working population in Indonesia to be employed in the manufacturing sector. Hence, if the Industry 4.0 is finally successful in Indonesia, the country will see a growth in GDP of at least 7\% each year 
between 2018 and 2030. Then, the manufacturing industry can be predicted to supply about $26 \%$ in the country by the year of 2030 .Now, in what ways will Indonesia achieve it? The problem is not becoming one of the top ten biggest global economies, but the process through it. The process covers all started from the beginning, that is, preparing the motivated employees or workers in each company in Indonesia. By having motivated employees, the jobs can be done smoothly, the organizations remain productive and finally the big goal in Indonesian economy can be achieved.

\section{Literature Review}

\section{The Era of Industry 4.0}

The development of the industrial revolutions has begun since two hundred and thirty years ago(Table 1). The first industrial revolution started with the invention and usage of mechanization, water power and steam power. It was simply related mostly to the needs of agriculture industry. Then, the second industrial revolution created mass production, assembly line and electrical energy in making products. It needed not only numbers of good machines to produce things but also many human resources as employees or workers for companies to carry out the job at that time. Next, the third round of revolution started the usage of computers and automation. It made the second model generation becoming less significant, and reduced slightly the numbers of industrial needs of human resources. Computers and automation help human's jobs so they can be done more effectively and efficiently. On the other hand, because of 'helping' human's jobs, employees, to some extent, are having their jobs to become lesser and lesser. Finally, for now, it has come to this phase, the fourth industrial revolutionary Industry 4.0. The revolution actually is the elaboration from the third revolution with software, hardware and networks to reach the next level of productivity. It is also the most important concept in the development of global industry and the world economy (Schwab, 2017).

Table 1. The Phase of Industrial Revolutions

\begin{tabular}{|l|c|c|}
\hline \multicolumn{1}{|c|}{ Phase } & Inventions & Year \\
\hline First Industrial Revolution (1.0) & Mechanization & Started in 1784 \\
& Water Power & \\
\hline Steam Power & Started in1870 \\
& Assembly Line \\
Third Industrial Revolution (3.0) & Automation & Started in1969 \\
& Computers & Today \\
\hline Fourth Industrial Revolution (4.0) & $\begin{array}{c}\text { Cyber Physical Systems } \\
\text { Internet of Things } \\
\end{array}$ & Big Data \\
& Artificial Intelligence & \\
\hline
\end{tabular}

The industrial revolution 4.0 was first introduced by Professor Klaus Schwab, starting with cyber-physical by industry, the virtual connectivity of all lines between human, machines and data. It is termed as a new level of organization control over the whole value chain of the life 
cycle of products which is matched towards increasingly individualized customer requirements (Vaidya et all, 2018).

As seen in Table 1, in Fourth Industrial Revolution, there are names which are mentioned. First, Cyber Physical Systems or CPS are used in manufacturing and control system. Second, Internet of Things or IoT refers to the system of networking that covers the whole worldwide in communicating also services. Third, Big data can be described as larger data both structured or unstructured that cannot be processed by traditional ways or techniques. Artificial Intelligence is the simulation of human intelligence that can be processed by machines, or systems. So, all of things mentioned in the fourth industrial revolution points out the sophisticated systems or concepts that will not only be supported but also main things that humans are going to attach in the next future.

Now, Industry 4.0 focuses on human integration that generates continuous improvement. As it is the expansion of the earlier industry revolution, the change of needs and usage cores including human's function in the industry is inevitable. Then, it is necessary to prepare for the best to survive in the latest phase of industry by learning the needs, specifically dealing with human resources regarding the fact that effective and efficient are still the main points in doing business.

\section{Employee Motivation}

Motivation derives from Latin word movere which means to move or drive (Steers and Porter; 1991). Motivation cannot be directly observable. But it can deal with things surround humans. Motivation has become very important for the last decades and has contributed a lot to human life after being acknowledged by Maslow in 1943 with his theory - Hierarchy of Needs. Now, motivation has many kinds of description according to the researchers, but the definition remains the same. As stated by Sheth and Mittal (2004), motivation can be described as things that can move humans and also the driving force for all human behaviour.While Spector (2003) explained that feeling and behavior of the employees towards their job are significantly influenced by their motivation and demotivation. In addition, Spector (2003) also mentioned that motivation is the internal state that makes employees to engage on specific behavior. Roos \& Eeden (2008) stated that motivation owned by an employee is the natural strength that can be formed and managed by a set of individualistic factors that can alter from time to time, depending on the special needs and motives of an employee.

There are two types of motivation. The first is the intrinsic motivation. According to Armstrong (2009), t intrinsic motivation can occur from the self-generated factors or it means by the employees themselves.

Dessler (2013), in Human Resource Management Handbook, stated that motivation derives from the pleasure someone gets from doing the job or task, which is called intrinsic motivation. It is surely within the workers or employees. For example, the feelings or emotions and the cognitive of the employees have can be related to enjoyment or satisfaction in completing their task. The feeling of the job owned is important, interesting and also challenging can be included as the impact of intrinsic motivation. So, it usually happens naturally from the humans or employees regarding the job.

The second is the extrinsic motivation. It is related to the external situation or condition surrounding the employees. Ryan and Deci (2000) described the extrinsic motivation as a concept that affects whenever an activity is done in order to accomplish some separable outcome. 
Armstrong (2009) mentions that extrinsic motivation appears when things are performed to or for people to drive them.

Some of the examples are reward, promotion or even punishment. If the employees really enjoy their work or job, the job will be worked out, and as for the consequences, it also can get achievement as recognition and rewards from the company or institution. So, the extrinsic motivation can be assumed as the drive to finalize or to put an end of the things that the employees intend to achieve.

Both intrinsic and extrinsic motivation can engage the employees to get the best result in doing their jobs. The intrinsic would be like the lever to carry out the job and the extrinsic would be the pedal of having that specific job.

\section{Discussion}

As the rapidity of the industry 4.0 goes on, it is also inevitable. Human resources should be prepared from time to time to make sure their capability is really suitable to compete in the industry 4.0. It does not only happen just in one country but the whole globe. Based on the study conducted by McKinsey in 2018, it was revealed that almost $78 \%$ Indonesian companies had consciousness of the concept of Industry 4.0.Indonesia has users of smartphone over 100 million. In addition, over 145 million of people are connected to the Internet - which is a huge number and it can be advantages to the realisation of Industry 4.0. Chromjakova (2016) stated that Industry 4.0 is a concept based on the electronic process control with minimum of human interventions in the setting process. Furthermore, the result of Chromjakova's project research concludes that with right motivated personnels, the company can achieve optimal performance from Industry 4.0 concept. Therefore, it means by preparing human resources to adapt the industrial revolution, here is Industry 4.0, the chance of success is bigger. Human resources can be pointed out as employees or workers that have already been there in the company. It doesn't only refer to the new job seekers, the new generation of employees or workers but also the employees that still work or do their jobs. As it is mentioned by the Vice Chairman of Labour Affairs of APINDO (referring to Indonesian Entrepreneur Association), Mr. Bob Azam, in the next ten years, Indonesia will be dealing with $60 \%$ employees that should be prepared for retraining because the competences now can be very different and perhaps incompetent regarding managing the future jobs (https:// infografik.bisnis.com/read/20190814/547/1136393/revolusi-industri-4.0-inovasi-dan-kualitassdm-indonesia).

By understanding Industry 4.0, the stakeholders can resolve what things should be taken into consideration and what should stay aside. Here, as the repetition of Indonesian government representatives worked through all means of media to make the stakeholders take into account about the importance of keeping up the employee motivation. It is necessary by letting surveys by the third part or by the company itself to understand employee motivation, retraining and developing employee skills - hardskills and softskills. The vocational training can be one of the keys to increase human resources quality in Indonesia. As an action at the beginning by Ministry of Labour in September 2019, the minister held panel discussion to socialize the vocational training for some targets. For the time being, the targets are the lower competence class labour, the people who got fired from the companies, people with disabilities, and more.(https://money.kompas.com/ $\mathrm{read} / 2019 / 09 / 23 / 184034326 /$ pentingnya-peningkatan-kualitas-sdm-pada-era-revolusi-industri40?page=all) 
For the employees of companies, there are some ways to boost employee motivation besides just sending the employees to a training or a course aggressively with the excuse of Industry 4.0. It can be done by maintaining the environment of the work. It can be considered as the extrinsic motivation, for examples managing the office into a green office, or having a ritual together in the office like having lunch together, or things that can be done together but it does not have to cost a lot of money from the company or by the employees. The point is to motivate the employees to do their jobs properly. After that, they can be equipped by training and development regarding to their needs or - actually the company needs to achieve the company's goal. With the more relaxing condition of working, the employees will not get burn out because of the stress and shock because of the work. If the employees get through it, then it is easier to motivate them or it could be the employees have engaged to the work so it will be better in achieve the company's goal. It means that the intrinsic motivation of the employees is accomplished. The importance of this paper is understanding employee motivation in order to help the companies to get through Industry 4.0. So namely all hard skills, or soft skills, both can be improved if the employees are motivated.

\section{Conclusion}

The industrial revolution really changes the world. The fourth industrial revolution or Industry 4.0 has come as the expansion of the third industrial revolution. Consequently, the countries in the world including Indonesia attempt to be the top ten countries of global economies in order to maintain the countries' welfare. In addition, industry 4.0 gives many opportunities to develop not only in terms of economy, manufacturing, science but also human resources. Many opinions of official in government, researchers and educators come to an understanding of the needs of human resources. Through human resources, anything is possible because employees are the assets of a company. In order to achieve the company's goal through employees, it is necessary to maintain the employees by considering their demands. The employee demands can be fulfilled if the company knows how to keep them satisfied and one way to do that is to motivate them.

Some suggestions related for future research especially in human resources specialty, it can be focused on employee motivation of specific job profiles, as well as on the development of specific job profiles in Industry 4.0.

\section{References}

Armstrong, Michael. 2009. Armstrong's Handbook of HRM Practice. $11^{\text {th }}$ edition. London Philadelphia, Kogan Page.

Chromjakova, Felicita. 2016. Flexible Man-Man Motivation Performance Management System for Industry 4.0. International Journal of Management Excellence, Vol.7, No. 2: $829-840$.

Hecklau, F., Galeitzke, M., Flachs, S. and Kohl, H.,2016. Holistic Approach for human Resource Management in Industry 4.0. Procedia CIRP, Vol. 54, pp. 1 - 6.

Sheth, J. and B. Mittal. 2004. Customer Behavior: Managerial Perspective. Second edition. Singapore: Thompson.

Steers, Richard M. andPorter, L.W. 1991. Motivation and Work Behavior. Fifth edition. McGraw-Hill, Inc.

Spector, P. E. 2003. Industrial and Organizational Psychology: Research and Practice. $3^{\text {rd }}$ ed. New York: John Wiley \& Sons, Inc. 
Roos,Wanda andEeden,René Van. 2008. The Relationship between Employee Motivation, Job Satisfaction and Corporate Culture. SA Journal of Industrial Psychology, Vol. 34 No. 1 , pp $54-63$

Ryan, R.M. and Deci, E.L. 2000. Intrinsic and Extrinsic Motivation: Classic Definitions and New Directions. Contemporary Educational Psychology, Vol. 25, pp 54 - 67

Vaidya, S., Ambad, P., and Boshle, S., 2018. Industry 4.0 - A Glimpse. Procedia Manufacturing. Vol. 20, pp $233-238$

https://www.cekindo.com/blog/industry-4-0-indonesia-challenges-opportunities

https://infografik.bisnis.com/read/20190814/547/1136393/revolusi-industri-4.0inovasi-dan-kualitas-sdm-indonesia

https://money.kompas.com/read/2019/09/23/184034326/pentingnya-peningkatankualitas-sdm-pada-era-revolusi-industri-40?page=all

https://www.thejakartapost.com/news/2019/08/31/building-indonesia-s-industry-40what-s-really-it-us.html 